• 研究报告・

\title{
千岛湖陆桥岛屿地表蚂蚁群落物种多样性 空间格局及其影响因素
}

\author{
周浩楠 赵郁豪 曾 頔 刘 娟 金挺浩 丁 平*
}

(浙江大学生命科学学院, 杭州 310058)

\begin{abstract}
摘要: 为了探讨千岛湖岛屿景观参数对地表蚂蚁群落物种 $\alpha$ 和 $\beta$ 多样性空间格局的影响, 作者分别于 2017 和 2018 年 的5-8月, 采用陷阱法、调落物分拣法和手捡法调查了千岛湖33个岛屿上的地表蚂蚁群落, 并依据食性将其划分为 捕食性蚂蚁和杂食性蚂蚁。利用回归模型分析了全部蚂蚁、捕食性蚂蚁和杂食性蚂蚁群落 $\alpha$ 和 $\beta$ 多样性与岛屿景观 参数的关系。结果表明, 岛屿面积对全部蚂蚁、捕食性蚂蚁和杂食性蚂蚁的物种丰富度均有显著的正向影响, 而 隔离度则无显著作用。蚂蚁群落的 $\beta$ 多样性由空间周转组分主导。岛屿面积差对全部蚂蚁、捕食性蚂蚁和杂食性 蚂蚁群落 $\beta$ 多样性的嵌套组分有正向影响, 隔离度差只对杂食性蚂蚁的总体 $\beta$ 多样性有正向影响。因此, 岛屿面积 是影响千岛湖地表蚂蚁群落物种丰富度的主要因素, 并且岛屿面积通过嵌套组分来影响蚂蚁群落的 $\beta$ 多样性, 表 现出选择性灭绝过程。此外, 不同食性蚂蚁可能因为扩散能力的差异对岛屿景观参数产生不同的响应。
\end{abstract}

关键词: 千岛湖; 生境片断化; 蚂蚁食性; 物种丰富度; $\beta$ 多样性

\section{Spatial patterns and influencing factors of ground ant species diversity on the land-bridge islands in the Thousand Island Lake, China}

Haonan Zhou, Yuhao Zhao, Di Zeng, Juan Liu, Tinghao Jin, Ping Ding*

College of Life Sciences, Zhejiang University, Hangzhou 310058

Abstract: To explore spatial patterns and environmental factors affecting ground ant species diversity in the Thousand Island Lake, China, we surveyed ground ants using pitfall traps, leaf litter extraction and hand collecting on 33 islands from May to August in 2017 and 2018. We divided all ground ants into predator or omnivore ants and then used the regression models to analyze relationships between ant species diversity and island attributes. Island area had positive effects on species richness of total ants, predator ants and omnivore ants; but isolation had no significant effects. The $\beta$ diversity of ants was dominated by spatial turnover component. Difference in island area had positive effects on the nestedness-resultant component of total ants, predator ants and omnivore ants communities. Difference in isolation had significant positive effects on the total $\beta$ diversity of omnivore ants. Island area was the main factor affecting spatial patterns of ant species richness. In addition, island area affected the $\beta$ diversity of ants via changing nestedness-resultant component, which indicates a selective extinction process in ant community assembly. Different responses of predator ants and omnivore ants to island attributes may be due to variation of dispersal ability.

Key words: Thousand Island Lake; habitat fragmentation; ant diet; species richness; $\beta$ diversity

城市化、人口扩张和农业发展等人类活动使大 片连续的生境被分割, 形成大小不一的斑块, 导致 生境片断化(Tilman et al, 2001)。生境片断化使得适 宜生境面积减少，且令各个生境斑块之间产生空间
上的隔离, 中心离边界的距离变小, 从而导致生物 多样性大量丧失, 进而改变生物群落的组成与结构 (Fahrig, 2003; Ewers \& Didham, 2006; Wilson et al, 2016)。因此, 深入了解生境片断化对物种多样性和 
群落的影响成为生态学和保护生物学的核心问题 之一(Ewers \& Didham, 2006; Laurance, 2008; Wilson et al, 2016)。其中生境片断化对生物多样性格局的 影响(Horvath et al, 2019; Liu et al, 2019; Loke et al, 2019; Uroy et al, 2019), 以及物种 $\alpha$ 和 $\beta$ 多样性对生 境片断化的响应及其机制(Filgueiras et al, 2019; Gavish et al, 2019; Hu et al, 2019; Souza et al, 2019) 越来越受到人们的关注。

$\alpha$ 多样性是局域内的物种数量(Whittaker, 1960), 即物种丰富度。片断化生境中的 $\alpha$ 多样性即是各生 境斑块的物种丰富度, 对其的研究可以为片断化生 境中物种的保护提供重要参考。岛屿生物地理学理 论(MacArthur \& Wilson, 1967)被认为是预测片断化 生境中物种丰富度格局的有效理论, 该理论认为岛 屿内的物种丰富度取决于岛屿内物种的灭绝和迁 入, 岛屿内物种的灭绝率随岛屿面积的增大而减小, 迁入率随隔离程度的增加而减小。一般来说, 面积 大、隔离度小的岛屿拥有更高的物种丰富度(Mac-
Arthur \& Wilson, 1967)。岛屿生物地理学理论目前 已被应用于各种类型的生境斑块, 为解释片断化生 境中的物种 $\alpha$ 多样性变化提供了有效的预测机制 (Fattorini et al, 2018; Lawrence et al, 2018; MacDonald et al, 2018; Takkis et al, 2018)。然而物种 $\alpha$ 多 样性只考虑物种数量的净增加或减少, 不能体现物 种组成变化的格局(Lennon et al, 2001); 而 $\beta$ 多样性 则可以衡量不同群落间物种组成的变化(Whittaker, 1960)。因此, 越来越多的研究开始关注物种 $\beta$ 多样 性格局及其影响因素(Veech \& Crist, 2007; Dobrovolski et al, 2012; Si et al, 2015; Wu et al, 2017)。

$\beta$ 多样性由两个潜在的生态学过程产生, 即物 种替换和物种丧失(Baselga，2012; Carvalho et al, 2012, 2013; Carvalho \& Cardoso, 2014)。物种替换是 由于环境或历史因素使得地点间一些物种被另外 一些物种替换的过程(Gaston, 2000; Qian et al, 2005; Baselga, 2010, 2012)。物种丧失是由于选择性灭绝、 迁入或扩散限制等机制使得地点间物种丰富度出 现差异(Novotny \& Weiblen, 2005; Urban et al, 2006; Ulrich et al, 2009; Carvalho et al, 2012)。当物种丰富 度的差异表现为小群落的物种组成是大群落的子 集时，嵌套格局就出现了(Patterson \& Atmar, 1986; Atmar \& Patterson, 1993)。已有研究表明, 探求 $\beta$ 多 样性格局的潜在机制应同时考虑物种替换和物种
丧失过程(Baselga, 2010; Carvalho et al, 2012; Si et al, 2015; Arcoverde et al, 2016), 这样才能更准确地 理解驱动不同群落间物种组成差异的潜在过程。

虽然应用 $\beta$ 多样性及其分解组分探究群落物种 组成变化的研究很多, 但主要集中在连续性的大陆 生境中(Yaacobi et al, 2007; Svenning et al, 2011; Calderon et al, 2013; Wen et al, 2016)。在片断化生境, 尤其是像浙江千岛湖这类由大坝修建而形成的陆 桥岛屿中，应用 $\beta$ 多样性分解方法分析物种组成变 化潜在机制及其影响因素的研究较少(Yong et al, 2012; Si et al, 2015; Wu et al, 2017)。此外，现有研究 较多关注外在因素(例如地理环境因子)的影响(Dorchin et al, 2018; Silva et al, 2018; Smith et al, 2018; Macedo et al, 2019), 对于物种生物学特性(例如物 种扩散能力、食性、种间关系)等影响片断化生境中 $\beta$ 多样性格局的研究较少(Badano et al, 2005; Meyer \& Kalko, 2008; Wu et al, 2017; González et al, 2018)。

蚂蚁是陆生无脊椎动物中的主要类群, 分布广 泛，对生境变化十分敏感(Andersen, 2018), 且易于 采样，是分析栖息地片断化对 $\beta$ 多样性影响的理想 研究对象。此外, 食性是生物体的重要特性, 从食 性角度解析物种丰富度和 $\beta$ 多样性格局可以为两类 格局的形成提供食物资源利用、竞争等方面的解释 (Badano et al, 2005; Meyer \& Kalko, 2008)。蚂蚁的 食性多样(Schultz \& McGlynn, 2000), 为研究食性 如何影响物种丰富度和 $\beta$ 多样性格局提供了机会。

本研究以千岛湖陆桥岛屿为研究平台, 调查了 33个陆桥岛屿上的蚂蚁群落，通过分析不同岛屿间 蚂蚁群落 $\beta$ 多样性及其与岛屿地理参数的关系, 尝 试探讨以下问题: (1)千岛湖陆桥岛屿上蚂蚁群落的 物种丰富度和 $\beta$ 多样性格局以及岛屿地理因子(岛屿 面积和隔离度)的影响。(2)不同食性蚂蚁的物种丰 富度和 $\beta$ 多样性格局及岛屿地理因子的影响是否有 差异?

\section{研究地概况}

千岛湖地处浙江省西部淳安县境内 $\left(29^{\circ} 22^{\prime}-\right.$ $\left.29^{\circ} 50^{\prime} \mathrm{N}, 118^{\circ} 34^{\prime}-119^{\circ} 15^{\prime} \mathrm{E}\right)$, 因1959年建造新安江 水力发电站，拦河建坝，湖水上涨，从而形成人工 湖泊。当水位达到 $108 \mathrm{~m}$ 时，水域面积为 $573 \mathrm{~km}^{2}$, 同 时形成 1,078 个面积大于 0.25 ha的陆桥岛屿(Yu et al, 2012)。气候为典型的亚热带季风气候, 温暖湿润, 
四季分明。年均温为 $17^{\circ} \mathrm{C}, 1$ 月最低 $\left(-7.6^{\circ} \mathrm{C}\right), 7$ 月最高 $\left(41.8^{\circ} \mathrm{C}\right)$ 。年均降水量为 $1,430 \mathrm{~mm}$, 主要集中在4-6 月。湖区植被以次生马尾松(Pinus massoniana)林为 主, 种类组成高度相似(张竞成等, 2008)。

\section{2 研究方法}

\section{1 调查岛屿设置}

2017和2018年的5-8月, 我们在千岛湖湖区选 取33个人为干扰少的岛屿(图1), 使用ArcGIS 10.5 基于1:10000的千岛湖地区遥感图像(水位高程为 $100 \mathrm{~m}$ )对它们的面积及隔离度进行测量与计算(附 录1)。其中, 隔离度采用岛屿边缘距最近大陆最短 距离(distance to the nearest mainland)。

\section{2 蚂蚁群落调查}

每个岛屿设置一到多条样线, 样线的数量与岛 屿面积的对数呈正比(附录1)。采用陷阱法、调落物 分拣法和手捡法调查33个岛屿上地表层的蚂蚁(包 含在地表层活动的树栖性蚂蚁)群落。(1)陷阱法: 每 条样线放置 20 个陷阱(根据样线长度增减陷阱数量), 陷阱间相距 $10 \mathrm{~m}$, 每个陷阱内倒入 $50 \mathrm{~mL}$ 酒精和乙 二醇混合液 $(1: 1)$ 作为陷阱液, 放置5 d后收集陷阱 中的蚂蚁。(2)调落物分拣法: 每条样线设置 5 个调 落物收集点(根据样线长度增减收集点数量), 收集 点间距40 m, 收集后置于Winkler袋中静置48 h后收 集蚂蚁标本。(3)手捡法: 每条样线安排 3 个人沿着 样线搜寻蚂蚁并收集, 搜寻时间为 $1.5 \mathrm{~h}$ (根据样线

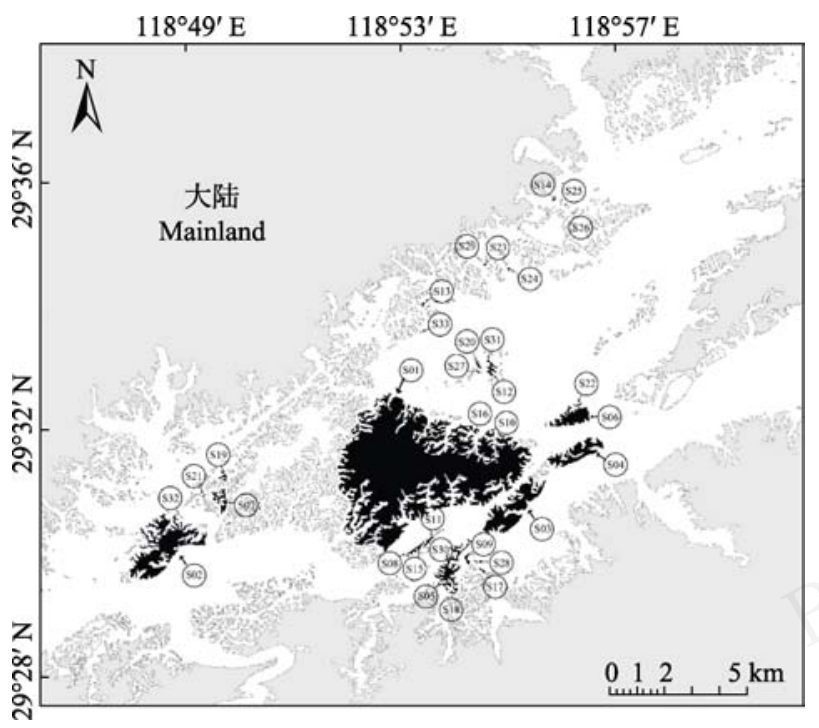

图1 千岛湖33个研究岛屿分布图

Fig. 1 Map of the 33 studied islands in the Thousand Island Lake, China
长度增减时间)。所有标本置于含有 $95 \%$ 酒精的离心 管中带回实验室。收集到的蚂蚁根据相关资料(周善 义，2001)鉴定到种，不能鉴定到种，但在形态上与 其他种明显有区别的, 以“属名 + sp.”命名。

蚂蚁的生态功能与它们在营养级中的位置密 切相关(Bluthgen et al, 2003; Gibb \& Cunningham, 2011; Pfeiffer et al, 2014), 且有研究表明蚂蚁属级 水平上的营养级较为稳定 (Gibb \& Cunningham, 2011)。根据已有文献(Pfeiffer et al, 2014; Gibb et al, 2018) 以及野外观察, 将本研究中的蚂蚁划分为捕 食性蚂蚁(predator ants)和杂食性蚂蚁(omnivore ants) 2 个功能群。捕食性蚂蚁只通过捕食无脊椎动物等 动物性食物作为食物来源, 杂食性蚂蚁不仅捕食无 脊椎动物, 也会取食植物来源的食物, 例如花蜜、 种子等(Holldobler \& Wilson, 1990; Brown, 2000; Bluethgen \& Feldhaar, 2010)。

\section{3 数据处理}

\subsection{1 调查完全性分析}

采用iNEXT (Hsieh et al, 2016) 软件包中的 ggiNEXT 和 iNEXT 函数, 做取样完成度 (sample coverage)曲线评估地表蚂蚁群落调查的完全性。

\subsection{2 物种丰富度}

统计每个岛上收集到的全部蚂蚁、捕食性蚂蚁 和杂食性蚂蚁的物种数, 作为它们在每个岛上的物 种丰富度。对物种丰富度和岛屿参数进行对数转换, 同时构建一元线性回归模型, 分析总体蚂蚁及不同 食性蚂蚁物种丰富度与岛屿面积和隔离度的关系。

\subsection{3 $\beta$ 多样性}

采用Andés Baselga提出的Sørensen成对相异性 指数 (pairwise Sørensen dissimilarity) $\beta_{\text {sor }}$ ) 计算所研 究岛屿上蚂蚁群落的 $\beta$ 多样性指数并将其分解为空 间周转组分 (turnover component)( $\left.\beta_{\text {sim }}\right)$ 和嵌套组分 (nestedness-resultant component)( $\left.\beta_{\text {sne }}\right)$ 。使用嵌套组 分在总 $\beta$ 多样性中的占有比例来表示嵌套组分的比 例, 即 $\beta_{\text {ratio }}=\beta_{\text {sne }} / \beta_{\text {sor }}$ 。如果 $\beta_{\text {ratio }}<0.5$, 则表示 $\beta$ 多样 性主要由物种空间周转决定; 若 $\beta_{\text {ratio }}>0.5$, 则表示 $\beta$ 多样性主要由嵌套组分贡献。

在分析 $\beta$ 多样性及其分解组分与岛屿参数的关 系时, 使用自变量基于距离矩阵的多重回归模型 (multiple regression model, MRM), 即首先计算岛屿 参数的欧几里得距离矩阵(Euclidean distance matrix), 然后使用MRM模型分别对岛屿参数距离矩阵进行 
回归, 获得回归斜率 (regression slope, $a$ ) 和截距 (intercept, $b$ )。由于两两岛屿间的成对观察并非完全 独立，因此为了避免空间自相关对结果估计的影响， 我们使用Mantel替代检验法(Mantel permutation test) 校对统计推断时产生的偏差, 并分别获得Pearson相 关系数 $r$ 和 $p$ 值。所有 $p$ 值通过 9,999 次Mantel替代后 得到。

本研究所有数据分析均在R 3.4.3 (R Core Team, 2016)中进行，所用的R软件包为: iNEXT、ggplot2、 betapart、ecodist、vegan。

\section{3 结果}

本研究共采集蚂蚁 91,011 头, 隶属于 8 亚科 44 属97种(附录2), 其中29种为捕食性蚂蚁(附录3), 占 全部蚂蚁物种数的 $29.9 \%, 68$ 种为杂食性蚂蚁(附录 $3)$, 占全部蚂蚁物种数的 $70.1 \%$ 。取样完成度曲线表 明调查岛屿的蚂蚁物种取样充分(附录4)。

全部蚂蚁、捕食性蚂蚁和杂食性蚂蚁的物种丰 富度均随着岛屿面积的增大而显著增加(图2a), 三 者 $Z$ 值(斜率)从大到小为捕食性蚂蚁 $(0.27)$ 、全部蚂 蚁 $(0.18)$ 和杂食性蚂蚁 $(0.15)$ 。隔离度对蚂蚁的物种 丰富度无显著影响(图2b)。

全部蚂蚁的 $\beta$ 多样性指数 $\left(\beta_{\mathrm{sor}}\right)$ 为 0.88 , 其中空 间周转组分 $\left(\beta_{\mathrm{sim}}\right)$ 为 0.76 , 嵌套组分 $\left(\beta_{\mathrm{sne}}\right)$ 为 0.12 , 嵌 套组分占比 $\left(\beta_{\text {ratio }}\right)$ 为 0.13 。不同食性蚂蚁的 $\beta$ 多样性 指数接近, 捕食性蚂蚁为 0.90 , 杂食性蚂蚁为 0.87 。 其中捕食性蚂蚁的嵌套组分高于杂食性蚂蚁, 而空 间周转组分则是捕食性蚂蚁低于杂食性蚂蚁。捕食 性蚂蚁的嵌套组分占 $\beta$ 多样性的比例要高于杂食性 蚂蚁(图3)。

岛屿面积和隔离度对全部蚂蚁及不同食性蚂 蚁 $\beta$ 多样性、空间周转和嵌套组分的影响存在差异 (图4, 5, 6)。岛屿面积差对全部蚂蚁和不同食性蚂蚁 的 $\beta$ 多样性 $\left(\beta_{\mathrm{sor}}\right)$ 无显著影响(图4A, $\left.5 \mathrm{~A}, 6 \mathrm{~A}\right)$, 而隔离 度差只对杂食性蚂蚁的 $\beta$ 多样性 $\left(\beta_{\mathrm{sor}}\right)$ 有显著的正向 作用(图6B)。 $\beta$ 多样性分解指数方面, 岛屿面积差对 全部蚂蚁和不同食性蚂蚁的 $\beta$ 多样性嵌套组分 $\left(\beta_{\mathrm{sne}}\right)$ 均存在显著的正向作用(图4E, 5E, 6E), 对空间周转 组分 $\left(\beta_{\mathrm{sim}}\right)$ 无显著影响(图4C, 5C, 6C)。隔离度差对全 部蚂蚁和不同食性蚂蚁的 $\beta$ 多样性分解组分均无显 著影响(图4D、F, 5D、F, 6D、F)。
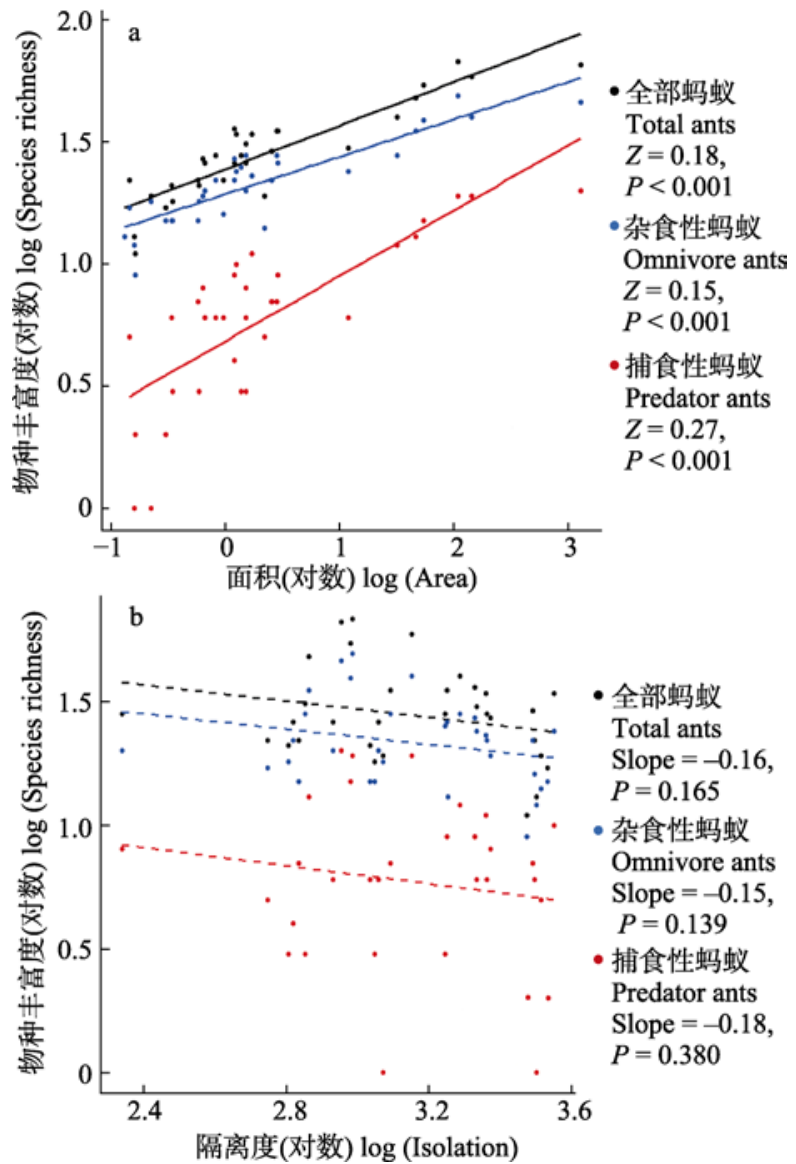

图2 全部蚂蚁、捕食性蚂蚁和杂食性蚂蚁的物种丰富度与 岛屿面积和隔离度的关系。有显著作用 $(P<0.05)$ 以实线表 示, 无显著作用以虚线表示。Slope: 斜率。

Fig. 2 Relationship of island area and isolation with species richness of total ants, predator ants and omnivore ants. Solid line indicates significant relationship at $P<0.05$. Dashed line indicates no significant relationship.

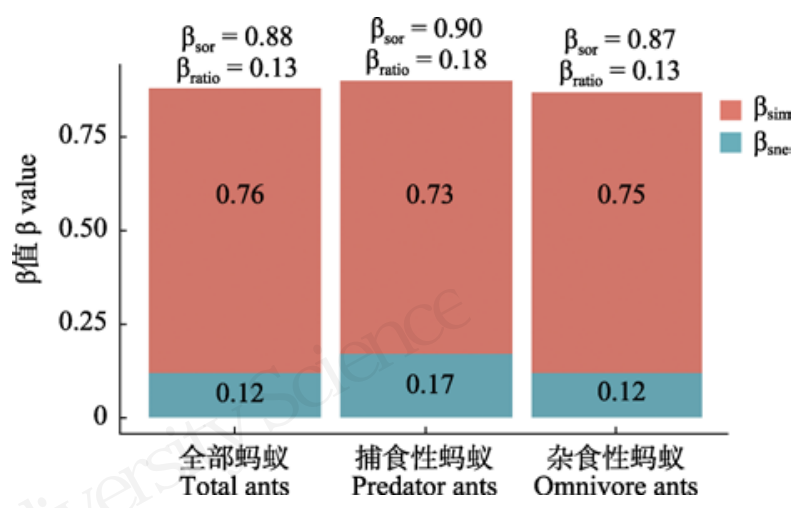

图3千岛湖调查岛屿上全部蚂蚁、捕食性蚂蚁和杂食性蚂 蚁的总体 $\beta$ 多样性指数及其组分分解。 $\beta_{\text {sor }}$ 表示Sørensen多岛 山与相异性指数, $\boldsymbol{\beta}_{\mathrm{sne}}$ 表示嵌套组分, $\boldsymbol{\beta}_{\mathrm{sim}}$ 表示空间周转组分, $\beta_{\text {ratio }}$ 表示嵌套组分占总体 $\beta$ 多样性指数的比例。

Fig. 3 The multiple-site Sørensen dissimilarity $\left(\beta_{\mathrm{sor}}\right)$ and its components of turnover $\left(\beta_{\text {sim }}\right)$ and nestedness-resultant $\left(\beta_{\text {sne }}\right)$ of total ants, predator ants and omnivore ants on the study islands in the Thousand Island Lake. $\beta_{\text {ratio }}=\beta_{\text {sne }} / \beta_{\text {sor }}$. 

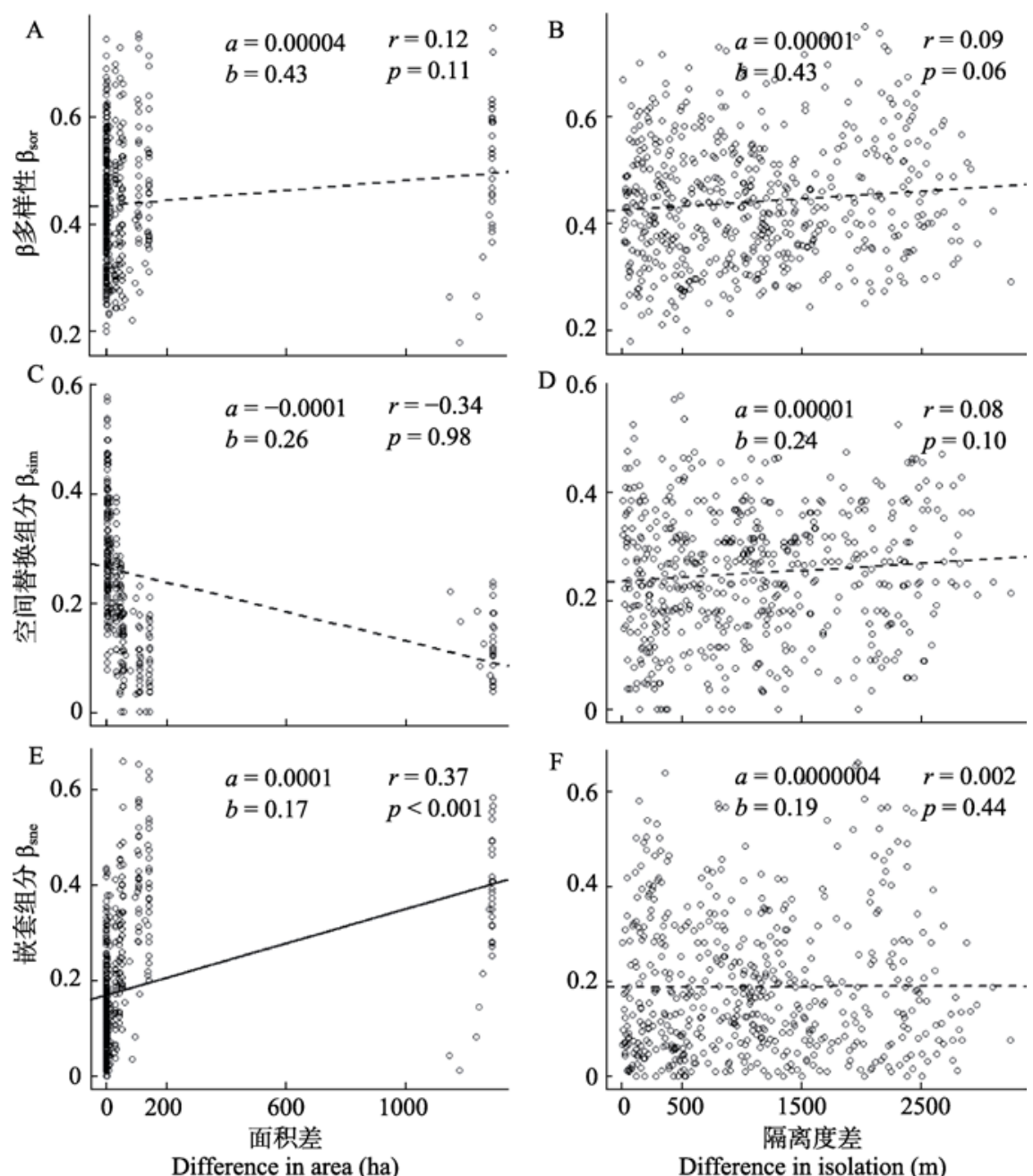

图4 岛屿参数对全部蚂蚁的 $\beta$ 多样性 $\left(\beta_{\mathrm{sor}}\right)$ 、空间周转组分 $\left(\beta_{\mathrm{sim}}\right)$ 和嵌套组分 $\left(\beta_{\mathrm{sne}}\right)$ 的影响。显著性结果 $(P<0.05)$ 以实线表示, 无显著结果以虚线表示。 $a$ : 回归模型的斜率; $b$ : 回归模型的截距; $r$ : Pearson相关系数; $p$ : mantel替代检验的 $p$ 值。

Fig. 4 The relationship of overall beta diversity $\left(\beta_{\text {sor }}\right)$ and its components of turnover $\left(\beta_{\text {sim }}\right)$ and nestedness-resultant $\left(\beta_{\text {sne }}\right)$, with difference in island area and isolation of total ant communities on study islands in Thousand Island Lake. Solid line shows the significant relationship at $P<0.05$, and dashed line shows no significant relationship. $a$, slope of multiple regression model; $b$, intercept of multiple regression model; $r$, Pearson correlation coefficient; $p$, $p$-value of Mantel permutation test.

\section{4 讨论}

本研究探讨了千岛湖陆桥岛屿上蚂蚁群落物 种丰富度和 $\beta$ 多样性格局以及岛屿参数对不同食性 蚂蚁群落多样性空间格局的影响。结果表明岛屿上 蚂蚁群落的物种丰富度及物种组成对岛屿参数的 响应不同。

\section{1 岛屿面积和隔离度对岛屿上蚂蚁物种丰富度 的影响}

本文结果表明, 全部蚂蚁、捕食性蚂蚁和杂食 性蚂蚁物种丰富度均随着岛屿面积增大而显著增 加。岛屿面积对蚂蚁物种丰富度表现出明显的面积 效应(MacArthur \& Wilson, 1967)。随着岛屿面积的
增大, 岛屿生境异质性增加, 生存资源增多, 从而 使得面积大的岛屿可维持的物种数增加(Burgman et al, 1988; Carvalho \& Cardoso, 2014; Warren et al, 2015), 造成物种丰富度随岛屿面积增大而增加的 格局。由于捕食性蚂蚁食物来源较窄, 当岛屿面积 减小, 食物资源更加有限, 捕食性蚂蚁的种间竞争 更加激烈(Hardin, 1960; Gray et al, 2007), 从而在小 岛屿上可维持的物种数更低, 导致捕食性蚂蚁的物 种丰富度对岛屿面积的变动更加敏感, 即种一面积 曲线中的 $Z$ 值较大。迄今, 千岛湖地区已开展了对多 种动物类群物种丰富度空间格局的研究。这些研究 结果均表明随岛屿面积增大物种丰富度也随之增 加, 但是不同动物类群对岛屿面积的敏感程度 $(Z$ 值) 

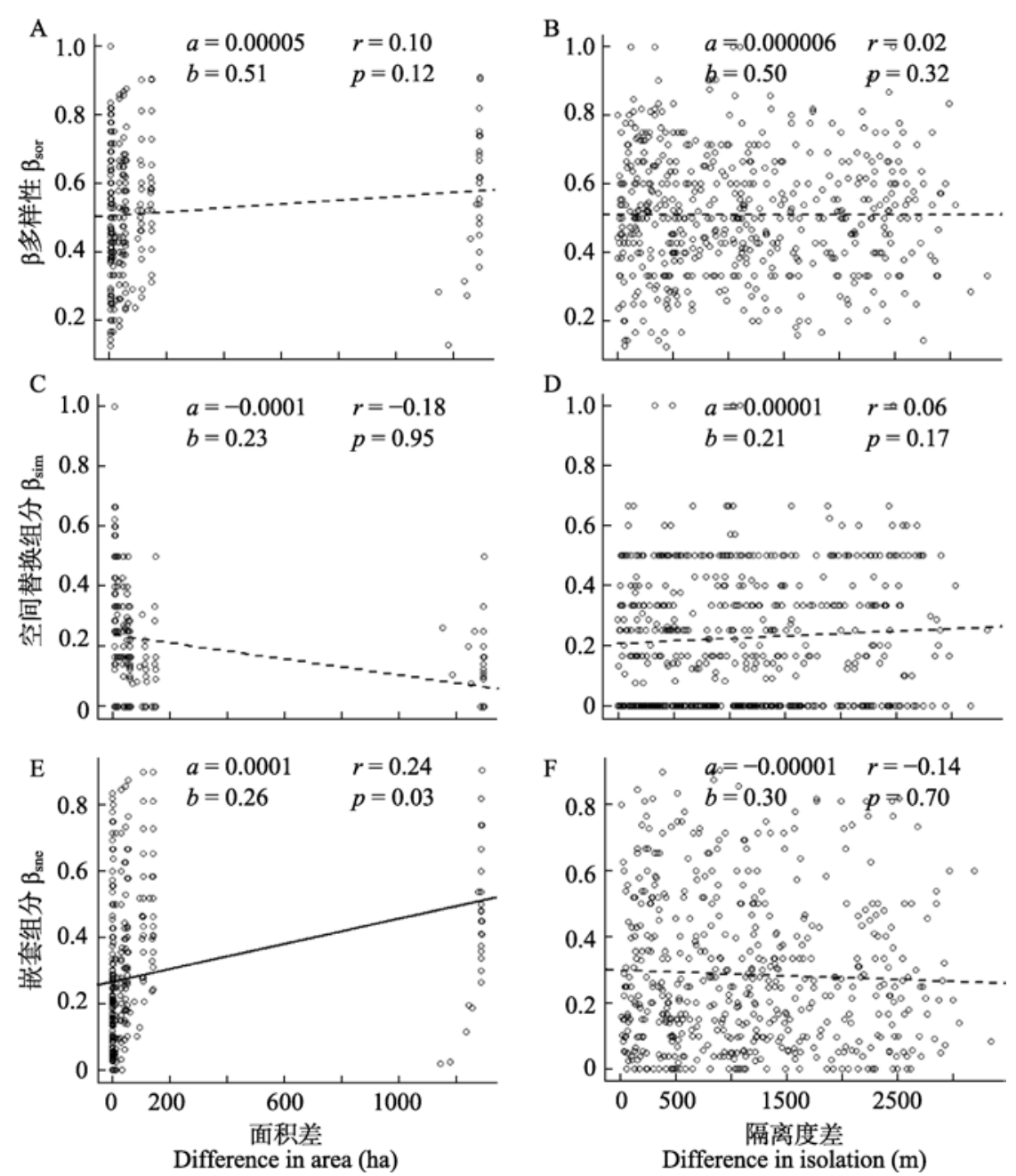

图5 岛屿参数对捕食性蚂蚁的 $\beta$ 多样性 $\left(\beta_{\mathrm{sor}}\right)$ 、空间周转组分 $\left(\boldsymbol{\beta}_{\mathrm{sim}}\right)$ 和嵌套组分 $\left(\boldsymbol{\beta}_{\mathrm{sn}}\right)$ 的影响。显著性结果 $(P<0.05)$ 以实线表示, 无显著结果以虚线表示。 $a$ : 回归模型的斜率; $b$ : 回归模型的截距; $r$ : Pearson相关系数; $p$ : mantel替代检验的 $p$ 值。

Fig. 5 The relationship of overall beta diversity $\left(\beta_{\text {sor }}\right)$ and its components of turnover $\left(\beta_{\text {sim }}\right)$ and nestedness-resultant $\left(\beta_{\text {sne }}\right)$, with difference in island area and isolation of predator ant communities on study islands in Thousand Island Lake. Solid line shows the significant relationship at $P<0.05$, and dashed line shows no significant relationship. $a$, slope of multiple regression model; $b$, intercept of multiple regression model; $r$, Pearson correlation coefficient; $p$, $p$-value of Mantel permutation test.

不同(王熙等, 2012; 徐爱春等, 2014; Si et al, 2015; Wu et al, 2017), 如繁殖鸟类(0.09)、结网蜘蛛(0.11)、 地表蜘蛛( 0.17$)$ 、地表蚂蚁(0.18)、蛙类 $(0.19)$ 、蜥蜴 类(0.24)、蛇类 $(0.26)$ 、非鼠类地栖哺乳动物(0.27) (附 录5)。可能的原因是: 繁殖鸟类、蜘蛛和蚂蚁通过 飞行或者飞航(Wu et al, 2017)在岛屿间移动较为频 繁, 从而对小岛屿上的物种有拯救作用(Devries et al, 1996; Forare \& Solbreck, 1997; Menendez \& Thomas, 2000), 使得在小岛屿上也能观测到较多物 种, 从而Z值较低; 两栖爬行类和非鼠类地栖哺乳 动物较少在岛屿间移动(Wang et al, 2010), 受到岛 屿资源限制较高, 相对鸟类、蜘蛛和蚂蚁而言, 它 们对岛屿面积的变动更加敏感。
隔离度在本研究中对全部蚂蚁及不同食性蚂 蚁的物种丰富度格局均无显著影响。一般认为，隔 离度对物种丰富度差异的影响主要与物种的扩散 能力有关(Ewers \& Didham, 2006)。已有研究表明, 蚂蚁扩散距离大都在 $100 \mathrm{~m}$ 以上(Helms, 2018), 而 千岛湖的岛屿间距离较小(吴奕如等, 2016), 蚂蚁可 以通过岛屿间的扩散到达离大陆较远的岛屿上，所 以隔离度对岛屿上蚂蚁群落的物种丰富度无显著 影响。

\section{2 岛屿面积和隔离度对岛屿上蚂蚁 $\beta$ 多样性格局} 的影响

本研究中岛屿上蚂蚁物种的 $\beta$ 多样性较高, 且 $\beta$ 多样性分解结果表明空间替换组分在 $\beta$ 多样性格局 

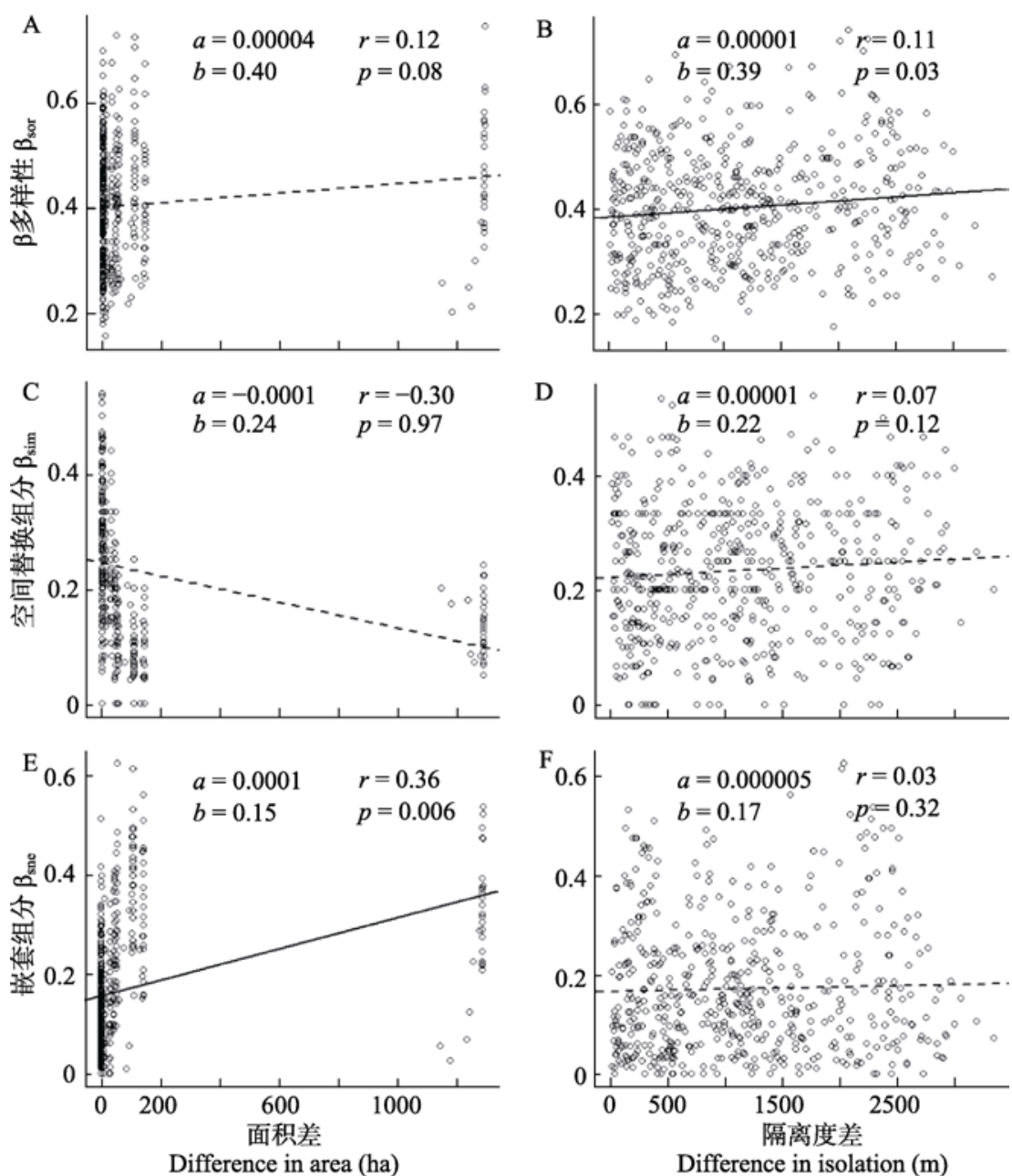

图6 岛屿参数对杂食性蚂蚁的 $\beta$ 多样性 $\left(\beta_{\mathrm{sor}}\right)$ 、空间周转组分 $\left(\boldsymbol{\beta}_{\mathrm{sim}}\right)$ 和嵌套组分 $\left(\boldsymbol{\beta}_{\mathrm{sne}}\right)$ 的影响。显著性结果 $(P<0.05)$ 以实线表示, 无显著结果以虚线表示。 $a$ : 回归模型的斜率; $b$ : 回归模型的截距; $r$ : Pearson相关系数; $p$ : mantel替代检验的 $p$ 值。

Fig. 6 The relationship of overall beta diversity $\left(\beta_{\text {sor }}\right)$ and its components of turnover $\left(\beta_{\text {sim }}\right)$ and nestedness-resultant $\left(\beta_{\text {sne }}\right)$, with difference in island area and isolation of omnivore ant communities on study islands in Thousand Island Lake. Solid line shows the significant relationship at $P<0.05$, and dashed line shows no significant relationship. $a$, slope of multiple regression model; $b$, intercept of multiple regression model; $r$, Pearson correlation coefficient; $p$, $p$-value of Mantel permutation test.

中占主导地位, 这与本研究地区关于鸟类、蜥蜴(Si et al, 2015)和蜘蛛(Wu et al, 2017)的 $\beta$ 多样性研究结 果一致。空间替换过程在千岛湖蚂蚁群落 $\beta$ 多样性 格局中占据主导地位可能与岛屿间的生境异质性 有关。蚂蚁是一类对生境变化十分敏感的生物 (Andersen, 2018), 即使是小生境的变化也会改变蚂 蚁群落的物种组成(Luque \& Lopez, 2007), 而岛屿 上多种小生境的存在对岛屿上蚂蚁群落的分布有 着重要影响(Wu et al, 2017)。此外, 捕食性蚂蚁的嵌 套组分占 $\beta$ 多样性的比例要高于杂食性蚂蚁, 可能 的原因为: 食物资源的限制导致捕食性蚂蚁的种间 竞争更加强烈(Hardin, 1960; Gray et al, 2007), 在食 物资源较少的小岛屿上，占据优势地位的捕食性蚂
蚁存留, 不占优势的捕食性蚂蚁被淘汰。而在大岛 屿上，因为食物资源更为充足，占据优势地位的捕 食性蚂蚁和弱势的捕食性蚂蚁有更大的共存可能 性，从而使得捕食性蚂蚁的嵌套组分在 $\beta$ 多样性中 所占的比例高于杂食性蚂蚁。

本研究结果显示岛屿面积差对岛屿上蚂蚁群 落的 $\beta$ 多样性指数 $\left(\beta_{\text {sor }}\right)$ 无显著影响, 但对 $\beta$ 多样性中 的嵌套组分有显著的正向影响。该结果表明千岛湖 岛屿上蚂蚁群落 $\beta$ 多样性与岛屿面积差无显著关系, 这可能是空间替换组分和嵌套组分相互抵消所带 来的结果(Baselga, 2010), 说明探讨环境参数对 $\beta$ 多 样性格局的影响不能只关注总体的 $\beta$ 多样性，也应 开展 $\beta$ 多样性分解组分与环境参数关系的分析，以 
获得更为具体实际的结果(Baselga, 2012; Si et al, 2015)。岛屿面积差与岛屿上蚂蚁群落 $\beta$ 多样性分解 组分的关系与千岛湖鸟类(Wang et al, 2010, 2011; Si et al, 2015)和蜘蛛(Wu et al, 2017)的研究结果一致, 均为随着岛屿面积差的增大, 空间周转组分减弱, 嵌套组分增强。岛屿面积差影响千岛湖地表蚂蚁群 落组成的潜在机理可能为选择性灭绝(Wang et al, 2011; Angeler, 2013)。随着大坝建成，水位迅速上涨， 在极短时间内使得原本连续的山顶被隔离成相互 孤立的岛屿。而原本生存在山顶的物种中, 对生境 和面积比较敏感的部分在小面积的岛屿上率先消 失。而在较大岛屿上同类物种则更多地被保留了下 来, 造成小岛屿上的物种组成大概率的成为大岛屿 上物种的子集，形成嵌套格局(Cutler, 1991; Wright \& Reeves, 1992; Wang et al, 2010)。当岛屿面积差较 小, 即调查岛屿面积相似时, 物种替换组分增加, 这表明各个岛屿均有各自的特有物种，且随着岛屿 面积的增大，更多的特有物种被保存下来，造成空 间周转组分的增加(Wu et al, 2017)。

通常岛屿隔离度对 $\beta$ 多样性的影响主要表现为 对迁入过程的影响(MacArthur \& Wilson, 1967), 由 于隔离度的差异, 导致不同的物种从大陆扩散到不 同距离岛屿上的可能性不同，从而造成岛屿间物种 组成的差异。本研究中捕食性蚂蚁和杂食性蚂蚁的 $\beta$ 多样性格局与隔离度差的关系的可能解释是：因 食性带来的不同资源限制导致它们在从大陆向岛 屿扩散的过程中表现不同(Tamburello et al, 2015)。 相比于杂食性蚂蚁, 捕食性蚂蚁受食物资源的限制 较大，倾向于扩散到更大的范围以获取足够的食 物。因此, 捕食性蚂蚁比杂食性蚂蚁可能扩散得更加 频繁或扩散距离更远，令捕食性蚂蚁的分布更加均 匀, 导致隔离度对捕食性蚂蚁 $\beta$ 多样性的影响不大。 本研究结果表明, 岛屿面积是影响千岛湖地表 蚂蚁群落物种丰富度的主要因素, 并且岛屿面积通 过嵌套组分来影响蚂蚁群落的 $\beta$ 多样性, 表现出选 择性灭绝过程。此外, 不同食性蚂蚁可能因为扩散 能力的差异对岛屿景观参数产生不同的响应。但由 于缺乏千岛湖成岛前的物种数据, 故而无法准确地 估计岛屿上蚂蚁群落的局部灭绝及其程度, 未来可 以在临近大陆上选择若干调查地点进行取样调查, 来深入研究千岛湖成岛后岛屿上蚂蚁物种的局域 灭绝情况。
致谢: 浙江省淳安县林业局和千岛湖国家森林公园 管理部门对研究给予支持, 广西师范大学周善义教 授和陈志林博士帮助鉴定蚂蚁标本, 千岛湖当地渔 民为本研究提供了合作与帮助，特此致谢!

\section{参考文献}

Andersen AN (2018) Responses of ant communities to disturbance: Five principles for understanding the disturbance dynamics of a globally dominant faunal group. Journal of Animal Ecology, 88, 350-362.

Angeler DG (2013) Revealing a conservation challenge through partitioned long-term beta diversity: Increasing turnover and decreasing nestedness of boreal lake metacommunities. Diversity and Distributions, 19, 772-781.

Arcoverde GB, Andersen AN, Setterfield SA (2016) Is livestock grazing compatible with biodiversity conservation? Impacts on savanna ant communities in the Australian seasonal tropics. Biodiversity and Conservation, 26, 1-15.

Atmar W, Patterson BD (1993) The measure of order and disorder in the distribution of species in fragmented habitat. Oecologia, 96, 373-382.

Badano EI, Regidor HA, Nunez HA, Acosta R, Gianoli E (2005) Species richness and structure of ant communities in a dynamic archipelago: Effects of island area and age. Journal of Biogeography, 32, 221-227.

Baselga A (2010) Partitioning the turnover and nestedness components of beta diversity. Global Ecology and Biogeography, 19, 134-143.

Baselga A (2012) The relationship between species replacement, dissimilarity derived from nestedness, and nestedness. Global Ecology and Biogeography, 21, 1223-1232.

Bluethgen N, Feldhaar H (2010) Food and shelter: How resources influence ant ecology. In: Ant Ecology (eds Lori L, Catherine LP, Kirsti LA), pp. 115-136. Oxford University Press, New York.

Bluthgen N, Gebauer G, Fiedler K (2003) Disentangling a rainforest food web using stable isotopes: Dietary diversity in a species-rich ant community. Oecologia, 137, 426-435.

Brown WL (2000) Diversity of ants. In: Ants: Standard Methods for Measuring and Monitoring Biodiversity (eds Agosti D, Majer JD, Alonso LE, Schultz TR), pp. 45-79, 231-269. Smithsonian Institution Press, Washington DC and London.

Burgman MA, Akcakaya HR, Loew SS (1988) The use of extinction models for species conservation. Biological Conservation, 43, 9-25.

Calderon PJM, Moreno CE, Pineda LR, Sanchez RG, Zuria I (2013) Vertebrate dissimilarity due to turnover and richness differences in a highly beta-diverse region: The role of spatial grain size, dispersal ability and distance. PLoS ONE, 8, e82905.

Carvalho JC, Cardoso P (2014) Drivers of beta diversity in 
Macaronesian spiders in relation to dispersal ability. Journal of Biogeography, 41, 1859-1870.

Carvalho JC, Cardoso P, Borges PAV, Schmera D, Podani J (2013) Measuring fractions of beta diversity and their relationships to nestedness: A theoretical and empirical comparison of novel approaches. Oikos, 122, 825-834.

Carvalho JC, Cardoso P, Gomes P (2012) Determining the relative roles of species replacement and species richness differences in generating beta-diversity patterns. Global Ecology and Biogeography, 21, 760-771.

Cutler A (1991) Nested faunas and extinction in fragmented habitats. Conservation Biology, 5, 496-505.

Devries HH, Denboer PJ, Vandijk TS (1996) Ground beetle species in heathland fragments in relation to survival, dispersal, and habitat preference. Oecologia, 107, 332-342.

Dobrovolski R, Melo AS, Cassemiro FAS, Diniz JAF (2012) Climatic history and dispersal ability explain the relative importance of turnover and nestedness components of beta diversity. Global Ecology and Biogeography, 21, 191-197.

Dorchin A, Dafni A, Izhaki I, Sapir Y, Vereecken NJ (2018) Patterns and drivers of wild bee community assembly in a Mediterranean IUCN important plant area. Biodiversity and Conservation, 27, 695-717.

Ewers RM, Didham RK (2006) Confounding factors in the detection of species responses to habitat fragmentation. Biological Reviews, 81, 117-142.

Fahrig L (2003) Effects of habitat fragmentation on biodiversity. Annual Review of Ecology, Evolution, and Systematics, 34, 487-515.

Fattorini S, Mantoni C, De Simoni L, Galassi DMP (2018) Island biogeography of insect conservation in urban green spaces. Environmental Conservation, 45, 1-10.

Filgueiras BKC, Melo DHA, Andersen AN, Tabarelli M, Leal IR (2019) Cross-taxon congruence in insect responses to fragmentation of Brazilian Atlantic forest. Ecological Indicators, 98, 523-530.

Forare J, Solbreck C (1997) Population structure of a monophagous moth in a patchy landscape. Ecological Entomology, 22, 256-263.

Gaston KJ (2000) Global patterns in biodiversity. Nature, 405, 220-227.

Gavish Y, Giladi I, Ziv Y (2019) Partitioning species and environmental diversity in fragmented landscapes: Do the alpha, beta and gamma components match? Biodiversity and Conservation, 28, 769-786.

Gibb H, Cunningham SA (2011) Habitat contrasts reveal a shift in the trophic position of ant assemblages. Journal of Animal Ecology, 80, 119-127.

Gibb H, Sanders NJ, Dunn RR, Arnan X, Vasconcelos HL, Donoso DA, Andersen AN, Silva RR, Bishop TR, Gomez C, Grossman BF, Yusah KM, Luke SH, Pacheco R, Pearce DJ, Retana J, Tista M, Parr CL (2018) Habitat disturbance selects against both small and large species across varying climates. Ecography, 41, 1184-1193.

González E, Buffa L, Defagó MT, Molina SI, Salvo A, Valladares $G$ (2018) Something is lost and something is gained: Loss and replacement of species and functional groups in ant communities at fragmented forests. Landscape Ecology, 33, 2089-2102.

Gray MA, Baldauf SL, Mayhew PJ, Hill JK (2007) The response of avian feeding guilds to tropical forest disturbance. Conservation Biology, 21, 133-141.

Hardin G (1960) Competitive exclusion principle. Science, 131, 1292-1297.

Helms JA (2018) The flight ecology of ants (Hymenoptera: Formicidae). Myrmecological News, 26, 19-30.

Holldobler B, Wilson EO (1990) The Ants. Belknap Press, Cambridge.

Horvath Z, Ptacnik R, Vad CF, Chase JM (2019) Habitat loss over six decades accelerates regional and local biodiversity loss via changing landscape connectance. Ecology Letters, 22, 1019-1027.

Hsieh TC, Ma KH, Chao A (2016) iNEXT: An R package for rarefaction and extrapolation of species diversity (Hill numbers). Methods in Ecology and Evolution, 7, 1451-1456.

Hu G, Wilson MC, Wu JG, Yu JJ, Yu MJ (2019) Decoupling species richness variation and spatial turnover in beta diversity across a fragmented landscape. PeerJ, 7, e6714.

Laurance WF (2008) Theory meets reality: How habitat fragmentation research has transcended island biogeographic theory. Biological Conservation, 141, 1731-1744.

Lawrence A, O’Connor K, Haroutounian V, Swei A (2018) Patterns of diversity along a habitat size gradient in a biodiversity hotspot. Ecosphere, 9, e02183.

Lennon JJ, Koleff P, Greenwood JJD, Gaston KJ (2001) The geographical structure of British bird distributions: Diversity, spatial turnover and scale. Journal of Animal Ecology, 70, 966-979.

Liu JJ, Coomes DA, Gibson L, Hu G, Liu JL, Luo YQ, Wu CP, Yu MJ (2019) Forest fragmentation in China and its effect on biodiversity. Biological Reviews, 94, 1636-1657.

Loke LHL, Chisholm RA, Todd PA (2019) Effects of habitat area and spatial configuration on biodiversity in an experimental intertidal community. Ecology, 100, e02757.

Luque GM, Lopez JR (2007) Effect of experimental smallscale spatial heterogeneity on resource use of a Mediterranean ground-ant community. Acta Oecologica-International Journal of Ecology, 32, 42-49.

MacArthur RH, Wilson EO (1967) The Theory of Island Biogeography. Princeton University Press, Princeton.

MacDonald ZG, Anderson ID, Acorn JH, Nielsen SE (2018) The theory of island biogeography, the sample-area effect, and the habitat diversity hypothesis: Complementarity in a naturally fragmented landscape of lake islands. Journal of Biogeography, 45, 2730-2743.

Macedo RLE, Quesada M, Neves FS (2019) Forest cover 
drives insect guild diversity at different landscape scales in tropical dry forests. Forest Ecology and Management, 443, 36-42.

Menendez R, Thomas CD (2000) Metapopulation structure depends on spatial scale in the host-specific moth Wheeleria spilodactylus (Lepidoptera: Pterophoridae). Journal of Animal Ecology, 69, 935-951.

Meyer CFJ, Kalko EKV (2008) Assemblage-level responses of phyllostomid bats to tropical forest fragmentation: Land-bridge islands as a model system. Journal of Biogeography, 35, 1711-1726.

Novotny V, Weiblen GD (2005) From communities to continents: Beta diversity of herbivorous insects. Annales Zoologici Fennici, 42, 463-475.

Patterson BD, Atmar W (1986) Nested subsets and the structure of insular mammalian faunas and archipelagoes. Biological Journal of the Linnean Society, 28, 65-82.

Pfeiffer M, Mezger D, Dyckmans J (2014) Trophic ecology of tropical leaf litter ants (Hymenoptera: Formicidae): A stable isotope study in four types of Bornean rain forest. Myrmecological News, 19, 31-41.

Qian H, Ricklefs RE, White PS (2005) Beta diversity of angiosperms in temperate floras of eastern Asia and eastern North America. Ecology Letters, 8, 15-22.

R Core Team (2016) R: A Language and Environment for Statistical Computing. http://www.r-project.org. (accessed on 2018-09-15)

Schultz TR, McGlynn TP (2000) The interactions of ants with other organisms. In: Ants: Standard Methods for Measuring and Monitoring Biodiversity (eds Agosti D, Majer JD, Alonso LE, Schultz TR), pp. 35-44, 231-269. Smithsonian Institution Press, Washington DC and London.

Si XF, Baselga A, Ding P (2015) Revealing beta-diversity patterns of breeding bird and lizard communities on inundated land-bridge islands by separating the turnover and nestedness components. PLoS ONE, 10, e0127692.

Silva DC, Vieira TB, Silva JM, Faria KC (2018) Biogeography and priority areas for the conservation of bats in the Brazilian Cerrado. Biodiversity and Conservation, 27, 815-828.

Smith DAE, Si XF, Smith YCE, Kalle R, Ramesh T, Downs CT (2018) Patterns of avian diversity across a decreasing patch-size gradient in a critically endangered subtropical forest system. Journal of Biogeography, 45, 2118-2132.

Souza DG, Sfair JC, Arroyo RV, Santos JC, Tabarelli M (2019) Depauperation and divergence of plant-specialist herbivore assemblages in a fragmented tropical landscape. Ecological Entomology, 44, 172-181.

Svenning JC, Flojgaard C, Baselga A (2011) Climate, history and neutrality as drivers of mammal beta diversity in Europe: Insights from multiscale deconstruction. Journal of Animal Ecology, 80, 393-402.

Takkis K, Kull T, Hallikma T, Jaksi P, Kaljund K, Kauer K, Kull T, Kurina O, Kulvik M, Lanno K, Leht M, Liira J,
Melts I, Pehlak H, Raet J, Sammet K, Sepp K, Vali U, Laanisto L (2018) Drivers of species richness and community integrity of small forest patches in an agricultural landscape. Journal of Vegetation Science, 29, 978-988.

Tamburello N, Cote IM, Dulvy NK (2015) Energy and the scaling of animal space use. The American Naturalist, 186, 196-211.

Tilman D, Fargione J, Wolff B, D’Antonio C, Dobson A, Howarth R, Schindler D, Schlesinger WH, Simberloff D, Swackhamer D (2001) Forecasting agriculturally driven global environmental change. Science, 292, 281-284.

Ulrich W, Almeida NM, Gotelli NJ (2009) A consumer's guide to nestedness analysis. Oikos, 118, 3-17.

Urban MC, Skelly DK, Burchsted D, Price W, Lowry S (2006) Stream communities across a rural-urban landscape gradient. Diversity and Distributions, 12, 337-350.

Uroy L, Ernoult A, Mony C (2019) Effect of landscape connectivity on plant communities: A review of response patterns. Landscape Ecology, 34, 203-225.

Veech JA, Crist TO (2007) Habitat and climate heterogeneity maintain beta-diversity of birds among landscapes within ecoregions. Global Ecology and Biogeography, 16, 650-656.

Wang X, Wang YP, Ding P (2012) Nested species subsets of amphibians and reptiles in Thousand Island Lake. Zoological Research, 33, 439-446. (in Chinese with English abstract) [王熙, 王彦平, 丁平 (2012) 千岛湖两栖爬行类动物 群落结构嵌套分析. 动物学研究, 33, 439-446.]

Wang YP, Bao YX, Yu MJ, Xu GF, Ding P (2010) Nestedness for different reasons: The distributions of birds, lizards and small mammals on islands of an inundated lake. Diversity and Distributions, 16, 862-873.

Wang YP, Chen SH, Ding P (2011) Testing multiple assembly rule models in avian communities on islands of an inundated lake, Zhejiang Province, China. Journal of Biogeography, 38, 1330-1344.

Warren BH, Simberloff D, Ricklefs RE, Aguilee R, Condamine FL, Gravel D, Morlon H, Mouquet N, Rosindell J, Casquet J, Conti E, Cornuault J, Fernandez-Palacios JM, Hengl T, Norder SJ, Rijsdijk KF, Sanmartin I, Strasberg D, Triantis KA, Valente LM, Whittaker RJ, Gillespie RG, Emerson BC, Thebaud C (2015) Islands as model systems in ecology and evolution: Prospects fifty years after MacArthur-Wilson. Ecology Letters, 18, 200-217.

Wen ZX, Yang QS, Quan Q, Xia L, Ge DY, Lü X (2016) Multiscale partitioning of small mammal diversity provides novel insights into the Quaternary faunal history of QinghaiTibetan Plateau and Hengduan Mountains. Journal of Biogeography, 43, 1412-1424.

Whittaker RH (1960) Vegetation of the Siskiyou Mountains, Oregon and California. Ecological Monographs, 30, 280-338.

Wilson MC, Chen XY, Corlett RT, Didham RK, Ding P, Holt RD, Holyoak M, Hu G, Hughes AC, Jiang L, Laurance WF, Liu JJ, Pimm SL, Robinson SK, Russo SE, Si XF, Wilcove 
DS, Wu JG, Yu MJ (2016) Habitat fragmentation and biodiversity conservation: Key findings and future challenges. Landscape Ecology, 31, 219-227.

Wright DH, Reeves JH (1992) On the meaning and measurement of nestedness of species assemblages. Oecologia, 92, 416-428.

Wu LB, Si XF, Didham RK, Ge DP, Ding P (2017) Dispersal modality determines the relative partitioning of beta diversity in spider assemblages on subtropical land-bridge islands. Journal of Biogeography, 44, 2121-2131.

Wu YR, Si XF, Chen CW, Zeng D, Zhao YH, Li JQ, Ding P (2016) Effects of dispersal abilities on community dynamics of breeding birds on the land-bridge islands in the Thousand Island Lake, China. Biodiversity Science, 24, 1135-1145. (in Chinese with English abstract) [吴奕如, 斯幸峰, 陈传 武, 曾頔, 赵郁豪, 李家琦, 丁平 (2016) 千岛湖陆桥岛 屿繁殖鸟类的扩散能力差异对群落动态的影响. 生物多 样性, 24, 1135-1145.]

Xu AC, Si XF, Wang YP, Ding P (2014) Camera traps and the minimum trapping effort for ground-dwelling mammals in fragmented habitats in the Thousand Island Lake, Zhejiang Province. Biodiversity Science, 22, 764-772. (in Chinese with English abstract) [徐爱春, 斯幸峰, 王彦平, 丁平
(2014) 千岛湖片段化栖息地地栖哺乳动物的红外相机监 测及最小监测时长. 生物多样性, 22, 764-772.]

Yaacobi G, Ziv Y, Rosenzweig ML (2007) Habitat fragmentation may not matter to species diversity. Proceedings of the Royal Society B: Biological Sciences, 274, 2409-2412.

Yong DL, Lohman DJ, Gan CW, Qie L, Lim SLH (2012) Tropical butterfly communities on land-bridge islands in Peninsular Malaysia. Raffles Bulletin of Zoology, 25, 161-172.

Yu MJ, Hu G, Feeley KJ, Wu JG, Ding P (2012) Richness and composition of plants and birds on land-bridge islands: Effects of island attributes and differential responses of species groups. Journal of Biogeography, 39, 1124-1133.

Zhang JC, Wang YP, Jiang PP, Li P, Yu MJ, Ding P (2008) Nested analysis of Passeriform bird assemblages in the Thousand Island Lake region. Biodiversity Science, 16, 321-331. (in Chinese with English abstract) [张竞成, 王彦 平, 蒋萍萍, 李鹏, 于明坚, 丁平 (2008) 千岛湖雀形目 鸟类群落嵌套结构分析. 生物多样性, 16, 321-331.]

Zhou SY (2001) Ants of Guangxi. Guangxi Normal University Press, Guilin. (in Chinese) [周善义 (2001) 广西蚂蚁. 广 西师范大学出版社, 桂林.]

(责任编委：陈圣宾 责任编辑：问文杰)

\section{附录 Supplementary Material}

附录1 千岛湖33个调查岛屿的景观参数、陷阱布设及蚂蚁物种丰富度

Appendix 1 Characteristics, ant traps and ant species richness of the 33 study islands in the Thousand Island Lake http://www.biodiversity-science.net/fileup/PDF/2019213-1.pdf

附录2 千岛湖研究岛屿上蚂蚁物种名录

Appendix 2 The list of ants in the Thousand Island Lake

http://www.biodiversity-science.net/fileup/PDF/2019213-2.pdf

附录3 千岛湖研究岛屿上蚂蚁物种基于属水平的食性划分

Appendix 3 Diet of each ant genus on study islands in the Thousand Island Lake http://www.biodiversity-science.net/fileup/PDF/2019213-3.pdf

附录4 千岛湖6个大岛蚂蚁物种取样完成度

Appendix 4 The sample coverage of ant species in six large islands in the Thousand Island Lake http://www.biodiversity-science.net/fileup/PDF/2019213-4.pdf

附录5 千岛湖地表蚂蚁种-面积关系与其他类群比较

Appendix 5 Comparison of species-area relationship between ground ants and other animal groups in the Thousand Island Lake http://www.biodiversity-science.net/fileup/PDF/2019213-5.pdf 
周浩楠，赵郁豪，曾頔，刘娟，金挺浩，丁平．千岛湖陆桥岛屿地表蚂蚁群落物种多样性空间格局及其影响 因素. 生物多样性, 2019, 27 (10): 1101-1111. http://www.biodiversity-science.net/CN/10.17520/biods.2019213

\section{附录1千岛湖 33 个调查岛屿的景观参数、陷阱布设及蚂蚁物种丰富度}

Appendix 1 Characteristics, ant traps and ant species richness of the 33 study islands in the Thousand Island Lake

\begin{tabular}{|c|c|c|c|c|c|c|c|}
\hline $\begin{array}{l}\text { 岛屿 } \\
\text { 编号 } \\
\text { Island } \\
\text { code }\end{array}$ & $\begin{array}{l}\text { 面积 } \\
\text { Area (ha) }\end{array}$ & $\begin{array}{l}\text { 隔离度 } \\
\text { Isolation } \\
\text { (m) }\end{array}$ & $\begin{array}{l}\text { 样线数 } \\
\text { Transect } \\
\text { line }\end{array}$ & $\begin{array}{l}\text { 样线长度 } \\
\text { Total } \\
\text { transect } \\
\text { length (m) }\end{array}$ & $\begin{array}{l}\text { 陷阱数 } \\
\text { Number } \\
\text { of total } \\
\text { pitfall } \\
\text { traps }\end{array}$ & $\begin{array}{l}\text { 凋落物样 } \\
\text { 本数 } \\
\text { Number of } \\
\text { leaflitter } \\
\text { samples }\end{array}$ & $\begin{array}{l}\text { 蚂蚁物 } \\
\text { 种数 } \\
\text { Number } \\
\text { of ant } \\
\text { species }\end{array}$ \\
\hline S01 & $1,289.232$ & 897.410 & 9 & 1,800 & 180 & 45 & 66 \\
\hline S02 & 143.193 & $1,415.090$ & 5 & 1,000 & 100 & 25 & 59 \\
\hline S03 & 109.031 & 964.970 & 5 & 1,000 & 100 & 25 & 68 \\
\hline S04 & 55.082 & 953.950 & 4 & 800 & 80 & 20 & 54 \\
\hline S05 & 46.370 & 729.800 & 3 & 600 & 60 & 15 & 48 \\
\hline S06 & 32.293 & $1,936.950$ & 3 & 600 & 60 & 15 & 40 \\
\hline S07 & 12.020 & $2,163.770$ & 2 & 400 & 40 & 10 & 30 \\
\hline S08 & 2.900 & $1,785.300$ & 1 & 200 & 20 & 5 & 35 \\
\hline S09 & 2.832 & $1,238.140$ & 1 & 200 & 20 & 5 & 35 \\
\hline S10 & 2.553 & $3,097.018$ & 1 & 200 & 20 & 5 & 29 \\
\hline S11 & 2.233 & $3,261.960$ & 1 & 200 & 20 & 5 & 19 \\
\hline S12 & 1.738 & $2,293.250$ & 1 & 200 & 20 & 5 & 34 \\
\hline $\mathrm{S} 13$ & 1.545 & 711.040 & 1 & 200 & 20 & 5 & 31 \\
\hline S14 & 1.535 & 219.075 & 1 & 200 & 20 & 5 & 28 \\
\hline S15 & 1.524 & 849.880 & 1 & 200 & 20 & 5 & 26 \\
\hline S16 & 1.399 & $1,760.340$ & 1 & 200 & 20 & 5 & 28 \\
\hline S17 & 1.255 & $3,547.037$ & 1 & 200 & 20 & 5 & 34 \\
\hline S18 & 1.202 & 657.720 & 1 & 190 & 19 & 5 & 26 \\
\hline S19 & 1.202 & $2,128.520$ & 1 & 200 & 20 & 5 & 36 \\
\hline S20 & 0.965 & $3,133.960$ & 1 & 170 & 17 & 5 & 22 \\
\hline S21 & 0.833 & $2,298.500$ & 1 & 140 & 14 & 4 & 28 \\
\hline S22 & 0.666 & $1,139.870$ & 1 & 130 & 13 & 4 & 26 \\
\hline S23 & 0.640 & $2,356.099$ & 1 & 150 & 15 & 4 & 27 \\
\hline S24 & 0.591 & 640.530 & 1 & 120 & 12 & 4 & 21 \\
\hline S25 & 0.586 & 684.553 & 1 & 90 & 9 & 3 & 22 \\
\hline S26 & 0.348 & $1,116.417$ & 1 & 80 & 8 & 3 & 18 \\
\hline S27 & 0.344 & $1,086.220$ & 1 & 80 & 8 & 3 & 21 \\
\hline S28 & 0.305 & $3,399.597$ & 1 & 90 & 9 & 3 & 17 \\
\hline S29 & 0.227 & $1,180.209$ & 1 & 80 & 8 & 3 & 19 \\
\hline S30 & 0.165 & $2,975.908$ & 1 & 50 & 5 & 2 & 11 \\
\hline S31 & 0.161 & $3,173.354$ & 1 & 50 & 5 & 2 & 13 \\
\hline $\mathrm{S} 32$ & 0.145 & 558.727 & 1 & 50 & 5 & 2 & 22 \\
\hline S33 & 0.133 & $1,788.795$ & 1 & 40 & 4 & 2 & 13 \\
\hline
\end{tabular}


周浩楠，赵郁豪，曾頔，刘娟，金挺浩，丁平．千岛湖陆桥岛屿地表蚂蚁群落物种多样性空间格局及其影响 因素. 生物多样性, 2019, 27 (10): 1101-1111. http://www.biodiversity-science.net/CN/10.17520/biods.2019213

\section{附录2 千岛湖研究岛屿上蚂蚁物种名录}

Appendix 2 The list of ants in the Thousand Island Lake

\begin{tabular}{|c|c|c|c|}
\hline 物种 & Species & 属 & Genus \\
\hline 日本尖尾蚁 & Acropyga nipponensis & 尖尾蚁属 & Acropyga \\
\hline 富川双节行军蚁 & Aenictus fuchuanensis & 双节行军蚁属 & Aenictus \\
\hline 苛氏双节行军蚁 & Aenictus hoelldobleri & 双节行军蚁属 & Aenictus \\
\hline 光柄双节行军蚁 & Aenictus laeviceps & 双节行军蚁属 & Aenictus \\
\hline 里氏钩猛蚁 & Anochetus risii & 钩猛蚁属 & Anochetus \\
\hline 大吉盘腹蚁 & Aphaenogaster geei & 盘腹蚁属 & Aphaenogaster \\
\hline 湖南盘腹蚁 & Aphaenogaster hunanensis & 盘腹蚁属 & Aphaenogaster \\
\hline$*$ & Bondroitia sp.1 & $*$ & Bondroitia \\
\hline 穴臭蚁属一种 & Bothriomyrmex sp.1 & 穴臭蚁属 & Bothriomyrmex \\
\hline 中华短猛蚁 & Brachyponera chinensis & 短猛蚁属 & Brachyponera \\
\hline 黄足短猛蚁 & Brachyponera luteipes & 短猛蚁属 & Brachyponera \\
\hline 黄斑弓背蚁 & Camponotus albosparsus & 弓背蚁属 & Camponotus \\
\hline 平和弓背蚁 & Camponotus mitis & 弓背蚁属 & Camponotus \\
\hline 弓背蚁属一种 & Camponotus sp.1 & 弓背蚁属 & Camponotus \\
\hline 少毛弓背蚁 & Camponotus spanis & 弓背蚁属 & Camponotus \\
\hline 东京弓背蚁 & Camponotus vitiosus & 弓背蚁属 & Camponotus \\
\hline 裸心结蚁 & Cardiocondyla nuda & 心结蚁属 & Cardiocondyla \\
\hline 网纹盲切叶蚁 & Carebara cribriceps & 盲切叶蚁属 & Carebara \\
\hline 针齿盲切叶蚁 & Carebara obtusidenta & 盲切叶蚁属 & Carebara \\
\hline 拟亮盲切叶蚁 & Carebara pseudolusciosa & 盲切叶蚁属 & Carebara \\
\hline 盲切叶蚁属一种 & Carebara sp.1 & 盲切叶蚁属 & Carebara \\
\hline 红盲切叶蚁 & Carebara vespillo & 盲切叶蚁属 & Carebara \\
\hline 立毛举腹蚁 & Crematogaster ferrarii & 举腹蚁属 & Crematogaster \\
\hline 大阪举腹蚁 & Crematogaster osakensis & 举腹蚁属 & Crematogaster \\
\hline 游举腹蚁 & Crematogaster vagula & 举腹蚁属 & Crematogaster \\
\hline 夫氏双凸切叶蚁 & Dilobocondyla fouqueti & 双凸切叶蚁属 & Dilobocondyla \\
\hline 卡氏无齿猛蚁 & Discothyrea kamiteta & 无齿猛蚁属 & Discothyrea \\
\hline 邵氏无齿猛蚁 & Discothyrea sauteri & 无齿猛蚁属 & Discothyrea \\
\hline 西伯利亚臭蚁 & Dolichoderus sibiricus & 臭蚁属 & Dolichoderus \\
\hline 爪哇扁头猛蚁 & Ectomomyrmex javanus & 扁头猛蚁属 & Ectomomyrmex \\
\hline 多毛真猛蚁 & Euponera pilosior & 真猛蚁属 & Euponera \\
\hline 棘棱结蚁 & Gauromyrmex acanthinus & 棱节蚁属 & Gauromyrmex \\
\hline 邵氏姬猛蚁 & Hypoponera sauteri & 姬猛蚁属 & Hypoponera \\
\hline 扁平虹臭蚁 & Iridomyrmex anceps & 虹臭蚁属 & Iridomyrmex \\
\hline 西昌刺结蚁 & Lepisiota xichangensis & 刺结蚁属 & Lepisiota \\
\hline 中华光胸臭蚁 & Liometopum sinense & 光胸臭蚁属 & Liometopum \\
\hline 同色小家蚁 & Monomorium concolor & 小家蚁属 & Monomorium \\
\hline 黑腹小家蚁 & Monomorium intrudens & 小家蚁属 & Monomorium \\
\hline 食草切叶蚁 & Myrmecina graminicola & 切叶蚁属 & Myrmecina \\
\hline 细纹切叶蚁 & Myrmecina strigis & 切叶蚁属 & Myrmecina \\
\hline 布氏尼氏蚁 & Nylanderia bourbonica & 尼氏蚁属 & Nylanderia \\
\hline
\end{tabular}


周浩楠，赵郁豪，曾頔，刘娟，金挺浩，丁平．千岛湖陆桥岛屿地表蚂蚁群落物种多样性空间格局及其影响 因素. 生物多样性, 2019, 27 (10): 1101-1111. http://www.biodiversity-science.net/CN/10.17520/biods.2019213

\begin{tabular}{|c|c|c|c|}
\hline 黄足尼氏蚁 & Nylanderia flavipes & 尼氏蚁属 & Nylanderia \\
\hline 全唇尼氏蚁 & Nylanderia integera & 尼氏蚁属 & Nylanderia \\
\hline 绣花尼氏蚁 & Nylanderia picta & 尼氏蚁属 & Nylanderia \\
\hline 无毛凹臭蚁 & Ochetellus glaber & 凹臭蚁属 & Ochetellus \\
\hline 山大齿猛蚁 & Odontomachus monticola & 大齿猛蚁属 & Odontomachus \\
\hline 邵氏拟立毛蚁 & Paraparatrechina sauteri & 拟立毛蚁属 & Paraparatrechina \\
\hline 长节大头蚁 & Pheidole fervens & 大头蚁属 & Pheidole \\
\hline 香港大头蚁 & Pheidole hongkongensis & 大头蚁属 & Pheidole \\
\hline 宽结大头蚁 & Pheidole nodus & 大头蚁属 & Pheidole \\
\hline 皮氏大头蚁 & Pheidole pieli & 大头蚁属 & Pheidole \\
\hline 大头蚁属一种 & Pheidole sp.1 & 大头蚁属 & Pheidole \\
\hline 大头蚁属一种 & Pheidole sp.2 & 大头蚁属 & Pheidole \\
\hline 阿禄斜结蚁 & Plagiolepis alluaudi & 斜结蚁属 & Plagiolepis \\
\hline 双齿多刺蚁 & Polyrhachis dives & 多刺蚁属 & Polyrhachis \\
\hline 梅氏多刺蚁 & Polyrhachis illaudata & 多刺蚁属 & Polyrhachis \\
\hline 结多刺蚁 & Polyrhachis rastellata & 多刺蚁属 & Polyrhachis \\
\hline 内氏前结蚁 & Prenolepis naoroji & 前结蚁属 & Prenolepis \\
\hline 刻纹棱胸切叶蚁 & Pristomyrmex punctatus & 棱胸切叶蚁属 & Pristomyrmex \\
\hline 伊藤卷尾猛蚁 & Proceratium itoi & 卷尾猛蚁属 & Proceratium \\
\hline 双齿唇拟毛蚁 & Pseudolasius bidenticlypeus & 拟毛蚁属 & Pseudolasius \\
\hline 污黄拟毛蚁 & Pseudolasius cibdelus & 拟毛蚁属 & Pseudolasius \\
\hline 光亮角腹蚁 & Recurvidris glabriceps & 角腹蚁属 & Recurvidris \\
\hline 弯刺角腹蚁 & Recurvidris recurvispinosa & 角腹蚁属 & Recurvidris \\
\hline 贾氏火蚁 & Solenopsis jacoti & 火蚁属 & Solenopsis \\
\hline 布农点猛蚁 & Stigmatomma bruni & 点猛蚁属 & Stigmatomma \\
\hline 西氏点猛蚁 & Stigmatomma silvestrii & 点猛蚁属 & Stigmatomma \\
\hline 犬齿瘤颚蚁 & Strumigenys canina & 瘤颚蚁属 & Strumigenys \\
\hline 台湾瘤颚蚁 & Strumigenys formosa & 瘤颚蚁属 & Strumigenys \\
\hline 六节瘤颚蚁 & Strumigenys hexamera & 瘤颚蚁属 & Strumigenys \\
\hline 平岛瘤颚蚁 & Strumigenys hirashimai & 瘤颚蚁属 & Strumigenys \\
\hline 细毛瘤颚蚁 & Strumigenys leptothrix & 瘤颚蚁属 & Strumigenys \\
\hline 刘氏瘤颚蚁 & Strumigenys lewisi & 瘤颚蚁属 & Strumigenys \\
\hline 截头瘤颚蚁 & Strumigenys mutica & 瘤颚蚁属 & Strumigenys \\
\hline 瘤颚蚁属一种 & Strumigenys sp.1 & 瘤颏蚁属 & Strumigenys \\
\hline 吉氏酸臭蚁 & Tapinoma geei & 酸臭蚁属 & Tapinoma \\
\hline 印度酸臭蚁 & Tapinoma indicum & 酸臭蚁属 & Tapinoma \\
\hline 黑头酸臭蚁 & Tapinoma melanocephalum & 酸臭蚁属 & Tapinoma \\
\hline 长角狡臭蚁 & Technomyrmex antennus & 狡臭蚁属 & Technomyrmex \\
\hline 褐狡臭蚁 & Technomyrmex brunneus & 狡臭蚁属 & Technomyrmex \\
\hline 角肩切胸蚁 & Temnothorax angulohumerus & 切胸蚁属 & Temnothorax \\
\hline 韩切胸蚁 & Temnothorax koreanus & 切胸蚁属 & Temnothorax \\
\hline 纳氏切胸蚁 & Temnothorax nassonovi & 切胸蚁属 & Temnothorax \\
\hline 切胸蚁属一种 & Temnothorax sp.1 & 切胸蚁属 & Temnothorax \\
\hline 浙江切胸蚁 & Temnothorax zhejiangensis & 切胸蚁属 & Temnothorax \\
\hline
\end{tabular}


周浩楠，赵郁豪，曾頔，刘娟，金挺浩，丁平. 千岛湖陆桥岛屿地表蚂蚁群落物种多样性空间格局及其影响 因素. 生物多样性, 2019, 27 (10): 1101-1111. http://www.biodiversity-science.net/CN/10.17520/biods.2019213

\begin{tabular}{clll} 
草地铺道蚁 & Tetramorium caespitum & 铺道蚁属 & Tetramorium \\
圆叶铺道蚁 & Tetramorium cyclolobium & 铺道蚁属 & Tetramorium \\
广西铺道蚁 & Tetramorium guangxiense & 铺道蚁属 & Tetramorium \\
光颚铺道蚁 & Tetramorium insolens & 铺道蚁属 & Tetramorium \\
克氏铺道蚁 & Tetramorium kraepelini & 铺道蚁属 & Tetramorium \\
茸毛铺道蚁 & Tetramorium lanuginosum & 铺道蚁属 & Tetramorium \\
日本铺道蚁 & Tetramorium nipponense & 铺道蚁属 & Tetramorium \\
史氏铺道蚁 & Tetramorium smithi & 铺道蚁属 & Tetramorium \\
罗氏铺道蚁 & Tetramorium wroughtonii & 铺道蚁属 & Tetramorium \\
叉唇细长蚁 & Tetraponera furcata & 细长蚁属 & Tetraponera \\
榕细长蚁 & Tetraponera microcarpa & 细长蚁属 & Tetraponera \\
埃氏扁胸切叶蚁 & Vollenhovia emeryi & 扁胸切叶蚁属 & Vollenhovia \\
\hline
\end{tabular}

* 无中文名 No Chinese name 
周浩楠，赵郁豪，曾頔，刘娟，金挺浩，丁平．千岛湖陆桥岛屿地表蚂蚁群落物种多样性空间格局及其影响 因素. 生物多样性, 2019, 27 (10): 1101-1111. http://www.biodiversity-science.net/CN/10.17520/biods.2019213

\section{附录3 千岛湖研究岛屿上蚂蚁物种基于属水平的食性划分}

Appendix 3 Diet of each ant genus on study islands in the Thousand Island Lake

\begin{tabular}{|c|c|c|c|}
\hline 亚科 & 属 & 食性 & 参考文献 \\
\hline Subfamily & Genus & Diet & References \\
\hline 钝猛蚁亚科 & 点猛蚁属 & 捕食性* & Shattuck, 1999 \\
\hline Amblyoponinae & Stigmatomma & Predator* & \\
\hline 臭蚁亚科 & 穴臭蚁属 & 杂食性* & Shattuck, 1999 \\
\hline \multirow[t]{13}{*}{ Dolichoderinae } & Bothriomyrmex & Omnivore* & \\
\hline & 臭蚁属 & 杂食性 & Shattuck, 1999 \\
\hline & Dolichoderus & Omnivore & \\
\hline & 虹臭蚁属 & 杂食性 & Shattuck, 1999 \\
\hline & Iridomyrmex & Omnivore & \\
\hline & 光胸臭蚁属 & 杂食性* & Field observation \\
\hline & Liometopum & Omnivore* & \\
\hline & 凹臭蚁属 & 杂食性 & Shattuck, 1999 \\
\hline & Ochetellus & Omnivore & \\
\hline & 酸臭蚁属 & 杂食性 & Shattuck, 1999 \\
\hline & Tapinoma & Omnivore & \\
\hline & 狡臭蚁属 & 杂食性 & Staab et al, 2014 \\
\hline & Technomyrmex & Omnivore & \\
\hline 行军蚁亚科 & 双节行军蚁属 & 捕食性 & Shattuck, 2008 \\
\hline Dorylinae & Aenictus & Predator & \\
\hline 蚁亚科 & 尖尾蚁属 & 杂食性 & Johnson et al, 2001 \\
\hline \multirow[t]{17}{*}{ Formicinae } & Acropyga & Omnivore & \\
\hline & 弓背蚁属 & 杂食性 & Gibb, 2012 \\
\hline & Camponotus & Omnivore & \\
\hline & 刺结蚁属 & 杂食性 & Brown, 2000 \\
\hline & Lepisiota & Omnivore & \\
\hline & 尼氏蚁属 & 杂食性 & La Polla et al, 2011 \\
\hline & Nylanderia & Omnivore & \\
\hline & 拟立毛蚁属 & 杂食性* & La Polla et al, 2011 \\
\hline & Paraparatrechina & Omnivore* & \\
\hline & 斜结蚁属 & 杂食性 & Shattuck, 1999 \\
\hline & Plagiolepis & Omnivore & \\
\hline & 多刺蚁属 & 杂食性 & Gibb, 2012 \\
\hline & Polyrhachis & Omnivore & \\
\hline & 前结蚁属 & 杂食性 & Staab et al, 2014 \\
\hline & Prenolepis & Omnivore & \\
\hline & 拟毛蚁属 & 杂食性 & Pfeiffer et al, 2014 \\
\hline & Pseudolasius & Omnivore & \\
\hline 切叶蚁亚科 & 盘腹蚁属 & 杂食性 & Brown, 2000 \\
\hline \multirow[t]{3}{*}{ Myrmicinae } & Aphaenogaster & Omnivore & \\
\hline & Bondroitia & 杂食性* & Field observation \\
\hline & & Omnivore* & \\
\hline
\end{tabular}


周浩楠，赵郁豪，曾頔，刘娟，金挺浩，丁平.千岛湖陆桥岛屿地表蚂蚁群落物种多样性空间格局及其影响 因素. 生物多样性, 2019, 27 (10): 1101-1111. http://www.biodiversity-science.net/CN/10.17520/biods.2019213

\begin{tabular}{|c|c|c|c|}
\hline & 心结蚁属 & 杂食性 & Shattuck, 1999 \\
\hline & Cardiocondyla & Omnivore & \\
\hline & 盲切叶蚁属 & 捕食性 & Shattuck, 1999 \\
\hline & Carebara & Predator & \\
\hline & 举腹蚁属 & 杂食性 & Shattuck, 1999 \\
\hline & Crematogaster & Omnivore & \\
\hline & 双凸切叶蚁属 & 杂食性* & Shattuck, 1999 \\
\hline & Dilobocondyla & Omnivore* & \\
\hline & 棱结蚁属 & 杂食性* & Hölldobler \& Wilson, \\
\hline & Gauromyrmex & Omnivore* & 1990 \\
\hline & 小家蚁属 & 杂食性 & Brown, 2000 \\
\hline & Monomorium & Omnivore & \\
\hline & 切叶蚁属 & 捕食性 & Shattuck, 2009 \\
\hline & Myrmecina & Predator & \\
\hline & 大头蚁属 & 杂食性 & Shattuck, 1999 \\
\hline & Pheidole & Omnivore & \\
\hline & 棱胸切叶蚁属 & 杂食性 & Staab et al, 2014 \\
\hline & Pristomyrmex & Omnivore & \\
\hline & 角腹蚁属 & 杂食性* & Field observation \\
\hline & Recurvidris & Omnivore* & \\
\hline & 火蚁属 & 杂食性 & Shattuck, 1999 \\
\hline & Solenopsis & Omnivore & \\
\hline & 瘤颚蚁属 & 捕食性 & Hölldobler \& Wilson, \\
\hline & Strumigenys & Predator & 1990 \\
\hline & 切胸蚁属 & 杂食性 & Fiedler et al, 2007 \\
\hline & Temnothorax & Omnivore & \\
\hline & 铺道蚁属 & 杂食性 & Shattuck, 1999 \\
\hline & Tetramorium & Omnivore & \\
\hline & 扁胸切叶蚁属 & 杂食性* & Shattuck, 1999 \\
\hline & Vollenhovia & Omnivore* & \\
\hline 猛蚁亚科 & 钩猛蚁属 & 捕食性 & Shattuck, 1999 \\
\hline Ponerinae & Anochetus & Predator & \\
\hline & 短猛蚁属 & 捕食性 & Suehiro et al, 2017 \\
\hline & Brachyponera & Predator & \\
\hline & 扁头猛蚁属 & 捕食性 & Schmidt \& Shattuck, \\
\hline & Ectomomyrmex & Predator & 2014 \\
\hline & 真猛蚁属 & 捕食性* & \\
\hline & Euponera & Predator* & \\
\hline & 姬猛蚁属 & 杂食性 & Shattuck, 1999 \\
\hline & Hypoponera & Omnivore & \\
\hline & 大齿猛蚁属 & 捕食性 & Shattuck, 1999 \\
\hline & Odontomachus & Predator & \\
\hline 卷尾猛蚁亚科 & 无齿猛蚁属 & 捕食性 & Brown, 1957 \\
\hline Proceratiinae & Discothyrea & Predator & \\
\hline
\end{tabular}


周浩楠，赵郁豪，曾頔，刘娟，金挺浩，丁平．千岛湖陆桥岛屿地表蚂蚁群落物种多样性空间格局及其影响 因素. 生物多样性, 2019, 27 (10): 1101-1111. http://www.biodiversity-science.net/CN/10.17520/biods.2019213

卷尾猛蚁属 捕食性* Staab et al, 2018

伪切叶蚁亚科

Proceratium Predator*

Pseudomyrmecinae 细长蚁属 杂食性* Field observation

*从亚科特性或野外观察推断

*Infer from subfamily and/or field observation 
周浩楠，赵郁豪，曾頔，刘娟，金挺浩，丁平. 千岛湖陆桥岛屿地表蚂蚁群落物种多样性空间格局及其影响 因素. 生物多样性, 2019, 27 (10): 1101-1111. http://www.biodiversity-science.net/CN/10.17520/biods.2019213

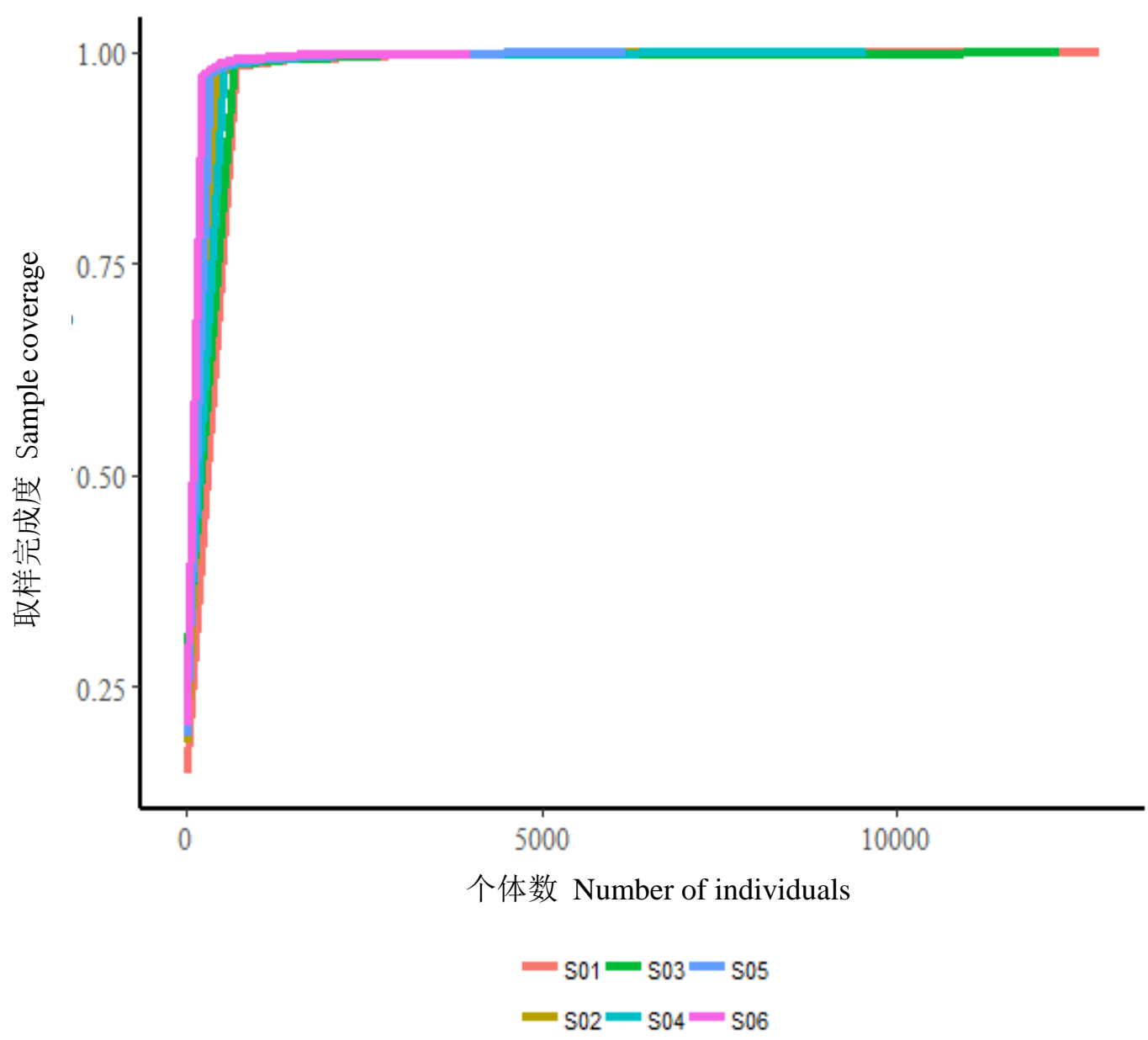

附录4 千岛湖6个大岛蚂蚁物种取样完成度

Appendix 4 The sample coverage of ant species in six large islands in the Thousand Island Lake 
周浩楠，赵郁豪，曾頔，刘娟，金挺浩，丁平. 千岛湖陆桥岛屿地表蚂蚁群落物种多样性空间格局及其影响 因素. 生物多样性, 2019, 27 (10): 1101-1111. http://www.biodiversity-science.net/CN/10.17520/biods.2019213

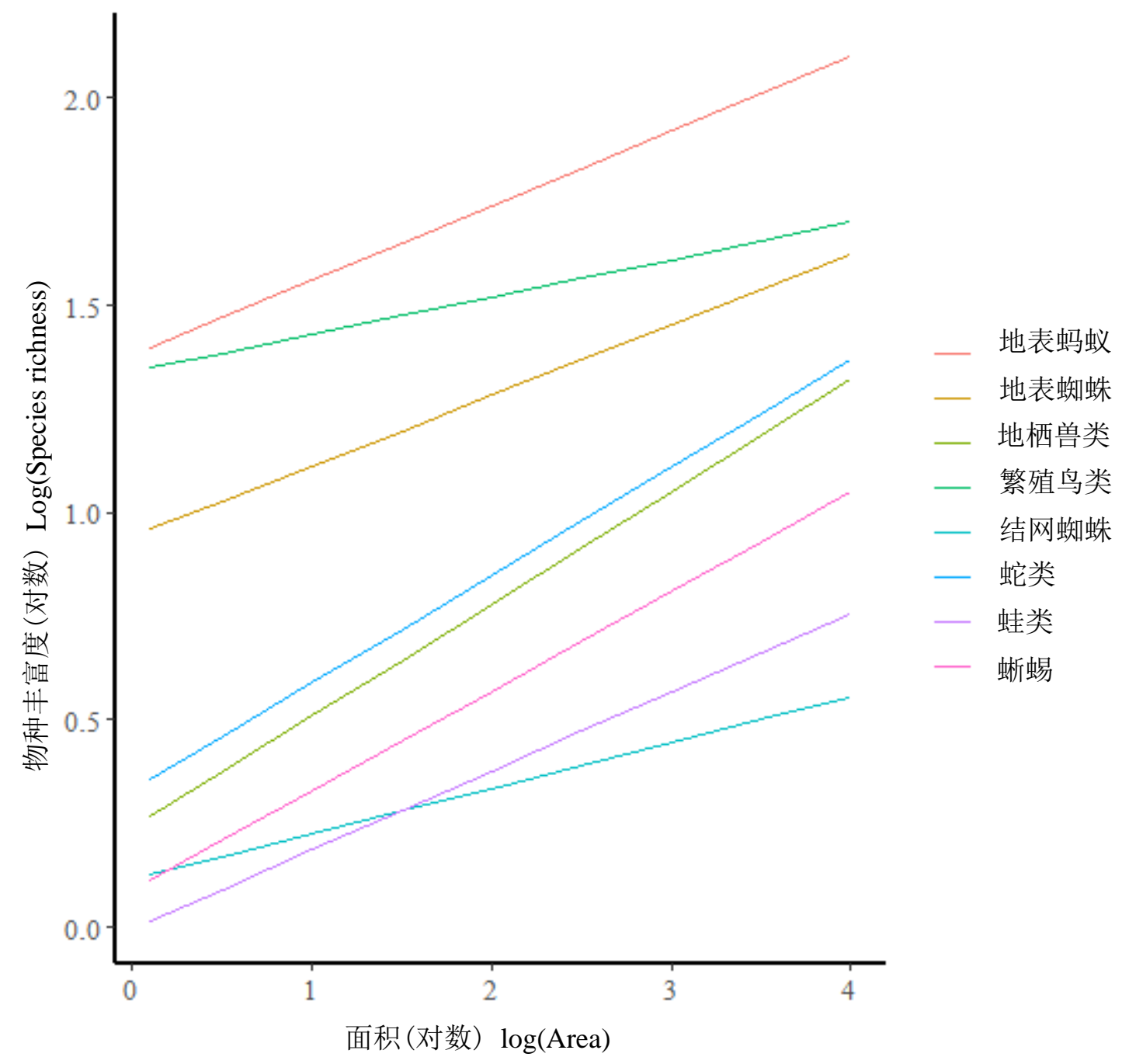

附录5 千岛湖地表蚂蚁种-面积关系与其他类群比较

Appendix 5 Comparison of species-area relationship between ground ants and other animal groups in the Thousand Island Lake 